\title{
Human-Rhino Conflict: Local People's Adaptation to Impacts of Rhino
}

\author{
Jyoti Sedhain ${ }^{1}$ and Anukram Adbikary ${ }^{2}$ \\ ${ }^{1}$ Multi Stakeholder Forestry Programme, ${ }^{2}$ ForestAction Nepal
}

\begin{abstract}
The greater one-horned rhinoceros, a protected species, significant to growing ecotourism industry and conservation efforts in Nepal poses a number of challenges to the local people residing in the vicinity of the Chitwan National Park (CNP). The article is based on a study of local people's perceptions on impacts of rhino and various coping and adaptation measures being adopted by them. The study also aims to explore ways to enhance adaptation by securing local people's participation in rhino conservation. Review of secondary literature, surveys, Focus Group Discussions (FGDs), and Likert scale analysis were carried out for the purpose of the study. Five per cent of the households (50) in Bachauli Village Development Committee that hosts Bagmara Buffer Zone Community Forest User Group of the CNP were randomly selected. The study found that despite 80 per cent of the respondents incurred damage in some form from rhinos, 40 per cent of them exhibited a positive perception towards rhino conservation. Among several coping and adaptive measures to damages, a combination of electric/solar fencing and trench is found to be most effective. Applied research through collaborations between social scientists and ecologists can help to address the gaps in the understanding of different elements of human-wildlife conflict .
\end{abstract}

Key words: Adaptation, buffer zone, Chitwan National Park, human-wildlife conflict, one horned rhinoceros

\section{INTRODUCTION}

In 2008, the International Union for Conservation of Nature (IUCN) revised its listing of the greater one-horned rhinoceros (Rhinoceros unicornis), one of the five remaining species of rhinoceros from 'endangered' to a less-threatened category of 'vulnerable' (IUCN 2008). Asiatic rhino species prefer to reside in the alluvial plain grasslands, and in adjacent swamps and forests where water and green grasses are available all year round. They were once widespread throughout the northern flood plains and nearby the foothills of the Indian sub-continent between IndoMyanmar border in the east and Sindh river basin, Pakistan in the west (Foose and van Strien 1997). Historically, the greater one-horned rhinoceros were distributed in Pakistan, India, Nepal, Bangladesh, Bhutan and Myanmar. Currently, the greater one-horned rhinoceros (hereafter rhinos) predominantly live in the flood plain ecosystem in Nepal and India (Dinerstein 2003). Their current populations are restricted to a few protected areas (PAs) of Nepal and India (Foose and van Strien 1997). In Nepal, these rhinos are found in several lowland PAs of Nepal. The latest count shows that there are a total of 645 rhinos in Nepal with 605 of them located in Chitwan National Park (CNP) (Rhino Count 2015).

Figure 1 depicts the trend of rhino population in Nepal from 1950 to 2015. Although the rhino population experienced a sharp decline during the mid1960s, the numbers have recovered since then. These figures are encouraging with respect to conservation efforts. However, as human population increases and natural wildlife habitats shrink, the incidents of people and wildlife coming into conflict 
over living space and food become more frequent and prominent. These impacts are diverse- people lose their crops (Pimentel et al. 2005; Perez and Pacheco 2006), livestock (Thirgood et al. 2005), properties (Woodroffe et al. 2005), and in some cases, even their lives (Loe and Roskaft 2004; Packer et al. 2005). Human-wildlife conflict is one of the main challenges to the continued survival of both wild species and local human populations in many parts of the world. If solutions to human-wildlife conflict are inadequate and ineffective, local support for conservation also declines (DNPWC 2007). This also holds true for the rhinos in Nepal. This paper intends to gauge the perception and attitude of local communities residing in and/or around the CNP toward rhino conservation and analyzes the intricacies of the humanwildlife conflict by focusing on the impacts of rhinos on local communities.

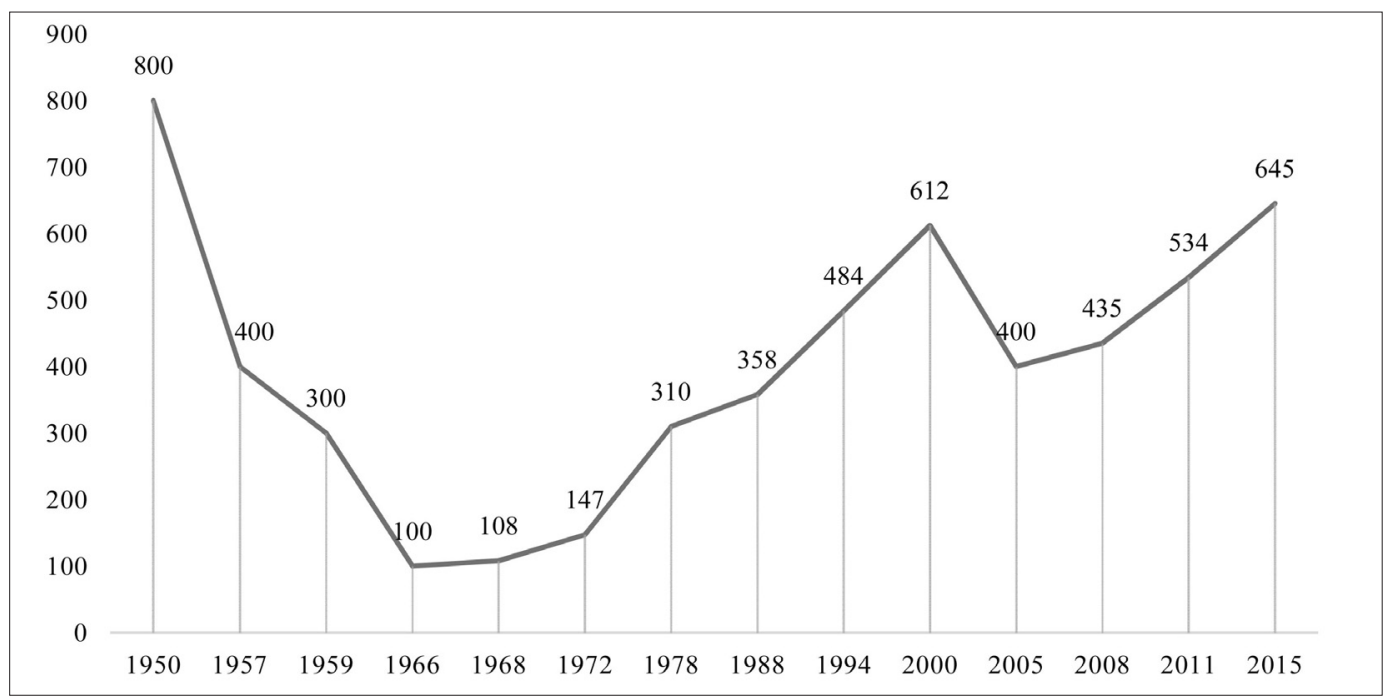

Figure 1. Trend of Rhino Population in Nepal between 1950 to 2015

Source: Rhino Count (2015)

The management of PAs has evolved from wildlife stock and endangered species-centered to more comprehensive approaches that emphasise on the collaboration and communications with the surrounding local communities (Ledec and Woodland 1990; Brandon and Wells 1992; Wells et al. 1992). The issue of human-wildlife conflict is crucial for conservation of the rhino population as well as livelihoods of local communities in Nepal. Participation of the local communities and their partnerships with PA authorities are vital to address challenges of human-wildlife conflict. Resolving human-wildlife conflict could lead to a win-win situation for both the locals and the rhinos. Ecotourism offers opportunities to this end, for instance tourism in and around CNP is largely driven by wildlife, especially the rhinos. Therefore, conservation of rhinos is integral to the tourism industry which is closely intertwined with the local livelihoods. Locals adapting and living in harmony with the rhinos offers economic potentials too. A thorough understanding about the impacts of rhinos on local communities would help in developing the best adaptation options in order to address 
human-wildlife conflict. With the aim of addressing these gaps, this paper aims to answer the following questions:

- What impacts have the rhinos had on the local communities?

- What is the local communities' perception and attitude towards rhino conservation?

- How do the local communities adapt to rhino impacts?

- What questions/research gaps need to be addressed pertaining to humanwildlife conflict in the context of Nepal?

\section{Human-wildlife Conflict: Impact on Local Livelihoods}

Human-wildlife conflict is a common phenomenon since time immemorial and yet, it continues to be a problem throughout the world even today (Lamarque et al. 2009; Wang and Macdonald 2005; Distefano 2004; Madden 2004). Crop raiding, property damage, livestock depredation, and human casualties are the most common forms of impacts from conflicts with wildlife (Ogra and Badola 2008; Inskip and Zimermann 2009). In addition to property damage and losses, the occasional threats to human lives aggravate sentiments of vulnerability of rural communities. Traditionally, the human response has been to kill the suspected wildlife and transform wild habitats to prevent further losses (Karanth and Madhusudan 2002; Jorgensen et al. 1978). However, with rising concern for wild animals and their conservation status, traditional lethal retaliation against wildlife is now illegal in some areas and/ or is deemed to be socially unacceptable in others (Treves and Naughton-Treves 2005; Knight 2003; Breitenmoser 1998).

With the rise in human population, natural habitats of rhinos were converted into agricultural fields. Large strips of land were cleared for agriculture and settlements, resulting in extensive habitat loss and fragmentation (Dinerstein 2003). Consequently, with time, the rhinos had to engage in some form of food competition with the livestock, leading to increment in crop depredation (WWF 2008). This led to the increment in the number of incidents related to local harassment and crop damage resulting in conflicts between the local people residing in the buffer zones in Nepal (DNPWC 2006). There are also conflicts between the local people and park authorities arising as a result of rhino's damage to crops and because of other difficulties posed by these animals. Thus a major source of parkpeople conflict is wildlife coming out of their natural habitats to settlement areas in search of food. The local communities who face these problems have often exhibited negative attitudes towards wildlife and/ or the PAs and their authorities in Nepal. Studies have shown that some people living adjacent to national parks feel that the government considers wildlife to be more valuable than local people, their safety, and livelihoods (Nepal and Weber 1993; Kharel 1997).

Protected areas in Nepal have positively contributed towards conservation of biodiversity; however, negative impacts on the socio-economic conditions of the people have also been observed as a result of this regime's strict regulations (Budhathoki 2001). Imposition of strict park regulations such as denying access to park resources have made lives of many poor communities very difficult. Strict implementation of such regulations contributed to increasing the population of wild animals including the rhinos, which negatively impacted the livelihoods of people living in the vicinity 
of PAs (Sharma and Shaw 1993; Nepal and Weber 1993). As a result, incidents of human-wildlife conflict have also risen.

Increasing crop damage and attacks on human life are furthering hostile attitudes among local people towards the preservation efforts of rhinos. Majority of the agricultural damage by rhino was recorded in Sauraha and neighboring villages along the park boundary. Crop preference of the rhino varied in different growing seasons, and losses incurred by the locals varied with vicinity of agricultural fields from the park. Flowering and early maturing stages of the crops were preferred by the rhinos (Jnawali 1989). These damages by the rhinos and other wildlife mainly occur due to the lack of any effective physical barrier(s) between private and/or public area, and the national park, which enables the rhinos to enter the human settlement freely. However, despite the dangers and damages posed by rhinos, the local people value rhinos and even equate them with national wealth. They believe that rhinos have a right to co-exist with the human population. McLean and Straede (2003) show that most people living within the vicinity of a park have a positive attitude toward nature conservation and PAs.

\section{STUDY AREA AND METHODS}

The study was carried in Bagmara Buffer Zone Community Forest (BZCF) of the CNP located in Bachauli Village Development Committee (VDC) of Chitwan (see Figure 2). The forest is bounded by community lands in the east and the west whereby the Khageri river flows in its southern and northern parts. The total area of the Bagmara BZCF is 215 hectare (ha) of which 163 ha has been naturally regenerated through community efforts. This BZCF group comprises of 1,017 households of Bachauli VDC (wards 1, 2, 3 and 4) as members. The members constitute of more than half of the population of the indigenous Tharu community residing in the VDC. Due to the availability of majority of its preferred plant species, the density of rhinoceros is high in this BZCF.

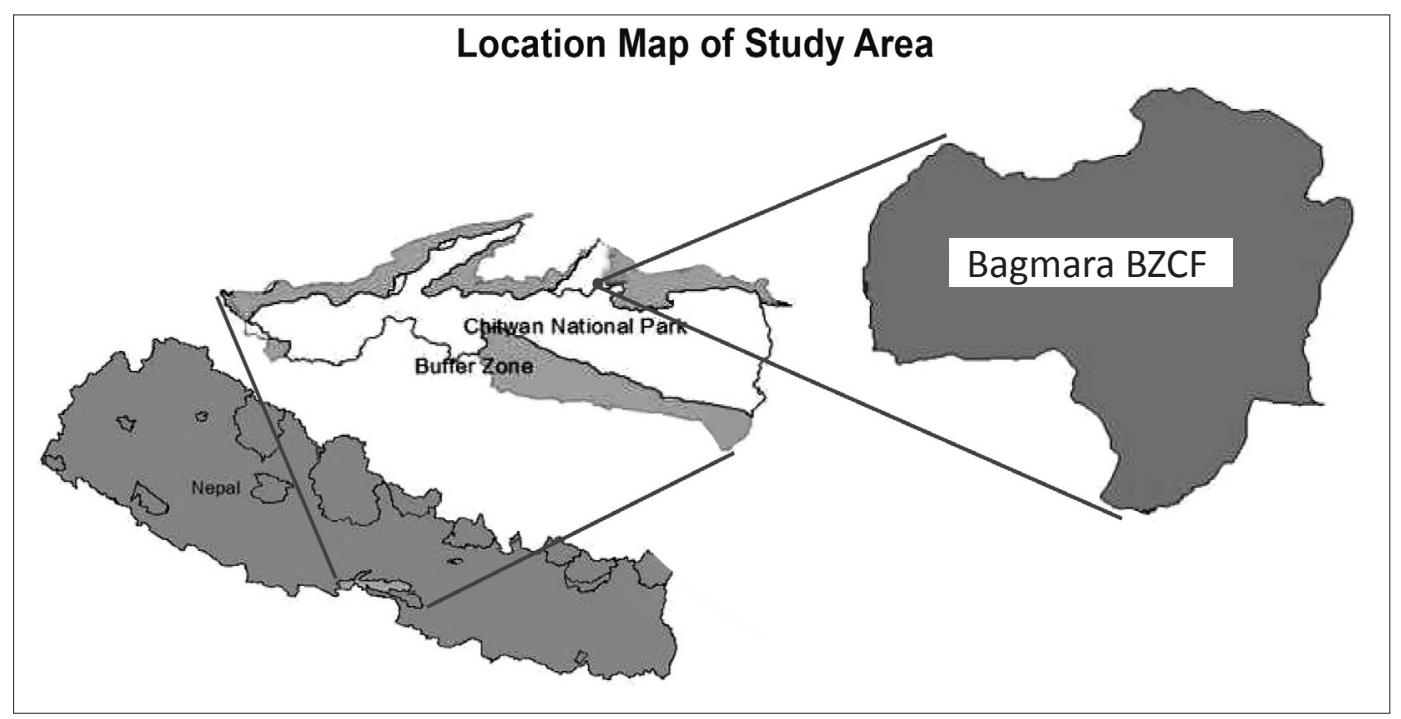

Figure 2. Bagmara BZCF in Chitwan National Park 
About 5 per cent (50) of the 1017 households were randomly sampled for the purpose of this study. Both primary and secondary data were collected and analysed in order to achieve the study objectives. For primary data collection, a reconnaissance survey was conducted. Participatory Rural Appraisal (PRA) and Rapid Rural Appraisal (RRA) were used to identify two types of households- one, in favor of rhino conservation, and another, against it. Primary data were also collected by carrying out four Focus Group Discussions (FGDs), and one general group discussion with the participation of different groups of people [victims, nonvictims, Executive Committee members of the Bagmara BZCF, staff members of the National Trust for Nature Conservation (NTNC) and the CNP].

Secondary data was collected from concerned PA, BZ management committee's records, VDCs, and different published (and unpublished) research reports, and journals. Furthermore, various researches and published reports by the Ministry of Forest and Soil Conservation (MoFSC), record data from NTNC and Department of National Park and Wildlife Conservation (DNPWC) were analysed.

\section{RHINO IMPACTS ON LOCAL COMMUNITY}

Both negative as well as positive impacts of rhino conservation on local communities were observed. The majority of the respondents $(80 \%)$ said they were negative about rhino's presence in their surroundings with the remaining 20 per cent positive about their presence.

Negative impacts of rhinos on local communities are categorized into crop damages, human loss, and others (physical destruction). Most of the agricultural damages by rhinos were recorded in Bodreni and Malpur villages located along the CNP boundary. Quite a large number of local people recalled incidents of either being chased, attacked, and/or even killed by rhinos each year. Among the negative impacts, crop damages were found to be the highest $(89 \%)$ in comparison to other impacts.

The rhinos' preference of crop items differed in different growing seasons. Moreover, losses incurred by the local communities varied with their respective distances from the CNP. It was found that the rhinos mostly preferred paddy $(60 \%)$ which was followed by wheat (15\%), maize $(15 \%)$ and other crops (10\%). It was also interesting to find that the rhinos damaged these crops during their flowering and/ or early maturing stages. As a result, the highest economic loss in rice crops was experienced. Moreover, few other plants were uprooted and chewed upon. The study also found that the mature crops were subject to more destruction $(78 \%)$ than others. Plants in their juvenile stages were found to be least destroyed (4\%) by the rhinos.

With regard to human loss, most of such incidents occurred outside the park while people were overseeing their grazing cattle, collecting fuel wood/fodder and fence materials, walking around in the evening, collecting snails and fishing in nearby rivers, and while attending local bush toilets. About 67 per cent of human casualty incidents due to rhino attack have occurred while people were tending to their crops in their respective agricultural fields. People have also lost their lives inside the park while they were busy during grass (thatch) cutting and/or engaging in illegal 
activities such as collecting fuel wood and other non-timber forest products (NTFPs) in the park without permission. Damages by rhinos to thatched roof houses and other physical infrastructure such as toilets and livestock sheds or shelters were also reported.

A number of positive impacts from the existence of rhinos were also cited by the respondents dwelling in the study area. Bagmara BZCF's annual income is around Nepalese Rupees (NRs.) 2-3 crores (or NRs. 20-30 million). Most of this income is generated by tourism-related activities.
Thousands of people visit the area only to get a glimpse of the rhino while on an elephant safari. According to the management committee of Bagmara BZCF, this business helps to provide employment to around $20-25$ people on a regular basis. Other employment generating activities such as hotels and showcasing the Tharu culture to visitors are closely intertwined with tourism-related activities in the region. When the respondents were asked about the benefits of rhino conservation, different types of benefits were revealed. These have been depicted in Figure 3.

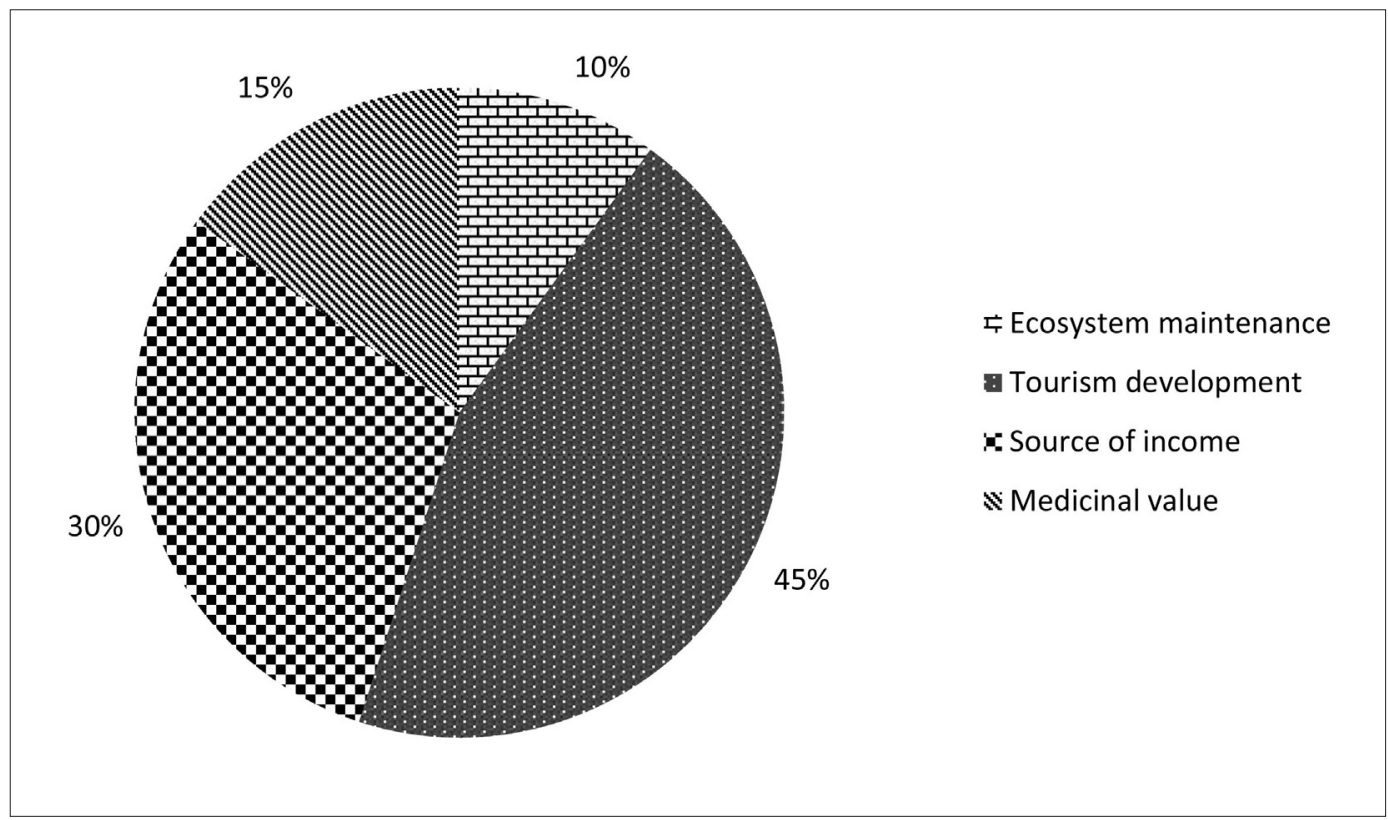

Figure 3. Benefits of Rhino Conservation

Likewise 45 per cent of the respondents believed that rhino conservation was crucial for the purpose of tourism development. Another 30 per cent said that rhinos were important sources of income for the region as a result of which their conservation is of significance. Some 15 per cent cited 'medicinal value' ${ }^{1}$ whilst 10 per cent of the respondents said that rhinos are integral for the ecological balance in the region and therefore, their conservation would positively affect the area's ecosystem in its entirety.

1 "Medicinal value" according to the local communities refer to the perceived medicinal value of the urine of the rhinos (as opposed to their 'horns'). Local communities in the study area have been known to use the rhino urine to cure ear ailments/ diseases and specific kinds of skin diseases as well. 


\section{PERCEPTION AND ATTITUDE OF LOCAL COMMUNITIES TOWARD RHINO CONSERVATION}

To measure the perception and attitudes of people towards rhinos and their conservation, a five-points Likert scale was developed and adopted. On a scale of 1 to 5, 1 represented "Strongly support/Very good" and 5 represented "Strongly Opposel Very bad".

Despite incurring damages from rhinos as aforementioned (crop-related, economic, human casualty, physical infrastructure, inter alia), it was interesting to find that majority (40\%) of the respondents showed strong positive attitude (or "Strongly support/Very good") towards rhino conservation. Respondents showing this strong positive attitude towards rhino conservation were those with minimum crop field/land holdings and are engaged in seasonal employment for their survival. About 5 percent of the respondents depicted strong anti-sentiments and negative attitude ("Strongly oppose/Very bad") toward rhino conservation because of the extent of damage(s) that they had incurred till date. The findings from the Likert scale analysis concerning the perception and attitude of locals towards rhino conservation have been presented in Figure 4.

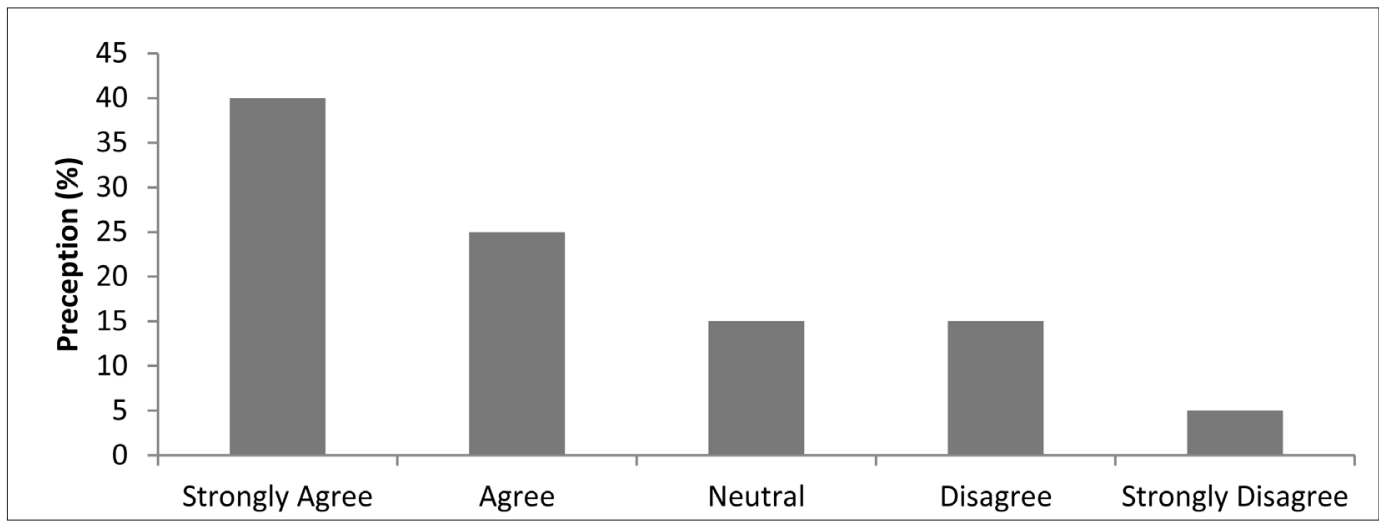

Figure 4. Local Peoples' Perception and Attitude toward Rhino Conservation

\section{COPING AND ADAPTATION MEASURES ADOPTED BY THE LOCAL COMMUNITY}

Adoption of coping and adaptation measures ${ }^{2}$ to either prevent or protect from damages incurred by rhinos is not a new concept. The locals in this region have been adopting a number of measures for a long period of time. For instance, machans ${ }^{3}$ are established at the entering points of rhinos to detect rhino movements. Sometimes machans are also built inside the field of maturing crops. Also, deep long trenches

\footnotetext{
${ }^{2}$ In the context of this study, 'coping measures' refers to the use of existing resources to achieve desired goals during and immediately after damage. Popular coping measures employed by the locals at the study sites included using rhino-scaring devices such as fire sticks, Ghuyetro, making loud sounds, leaving goods/items behind, submerging and/or sinking into a water body, and gathering tree support. Among these, the last three coping measures were mostly used to avoid situations that can potentially lead to human casualties. Similarly, 'adaptation measures' constitute of activities that contribute to reducing the negative impacts of rhino by taking advantage of whatever new opportunities that may be presented. Some of the adaptation measures that were employed at the study area included electric/solar fencing, trench, mesh wire fencing, biofencing, machan guarding, and water ponds among others.

${ }^{3} \mathrm{~A}$ machan is a type of a safety platform that is founded at a certain height from the ground level- on a tree or with the support of poles- to oversee various activities that are taking place at the ground level.
} 
of about $1-1.5 \mathrm{~m}$ depth are dug along the park boundary to deter rhinos from entering settlement areas. Various types of fences are also erected by local farmers along the field boundaries- some use thorny shrub species while some plant canes of tall grasses that act as bio-fences. Another traditional practice is placing of a tin bell at the middle of the field of maturing crop items; the tin bell rings when there is disturbance in the area, generally signifying the presence of a rhino. One of the most traditional coping mechanisms used by the indigenous Tharu community in avoiding contact with rhinos is the use of "Ghuyetro". It is a method in which the people make loud voices by hitting on small tin boxes, shaking plastic objects, and thronging dust and stones. A ranking of these coping and adaptation measures by the local respondents have been presented in Figures 5 and 6 respectively.

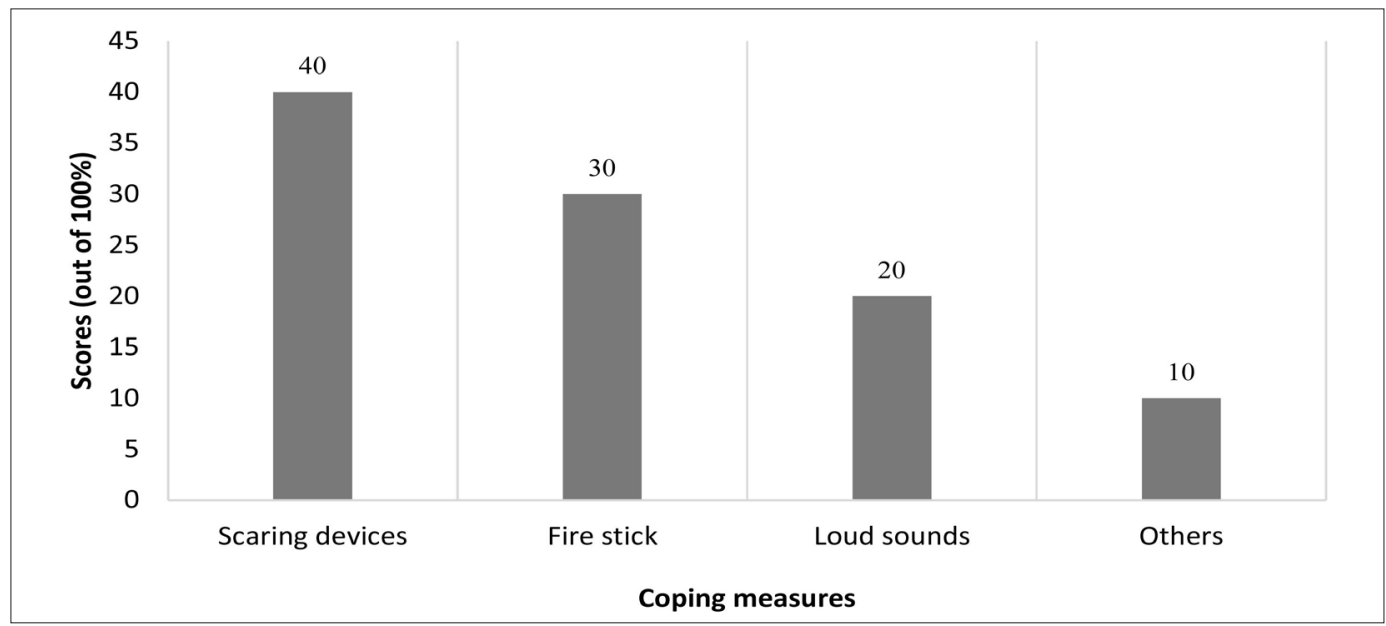

Figure 5. Ranking of Different Coping Measures by the Respondents

It can be inferred from Figure 5 that the stick' (30\%), 'Loud sounds' (20\%) and most preferred coping measure among 10 per cent of the respondents preferred the respondents was the usage of 'Scaring 'Others'. devices' (40\%), followed closely by 'Fire

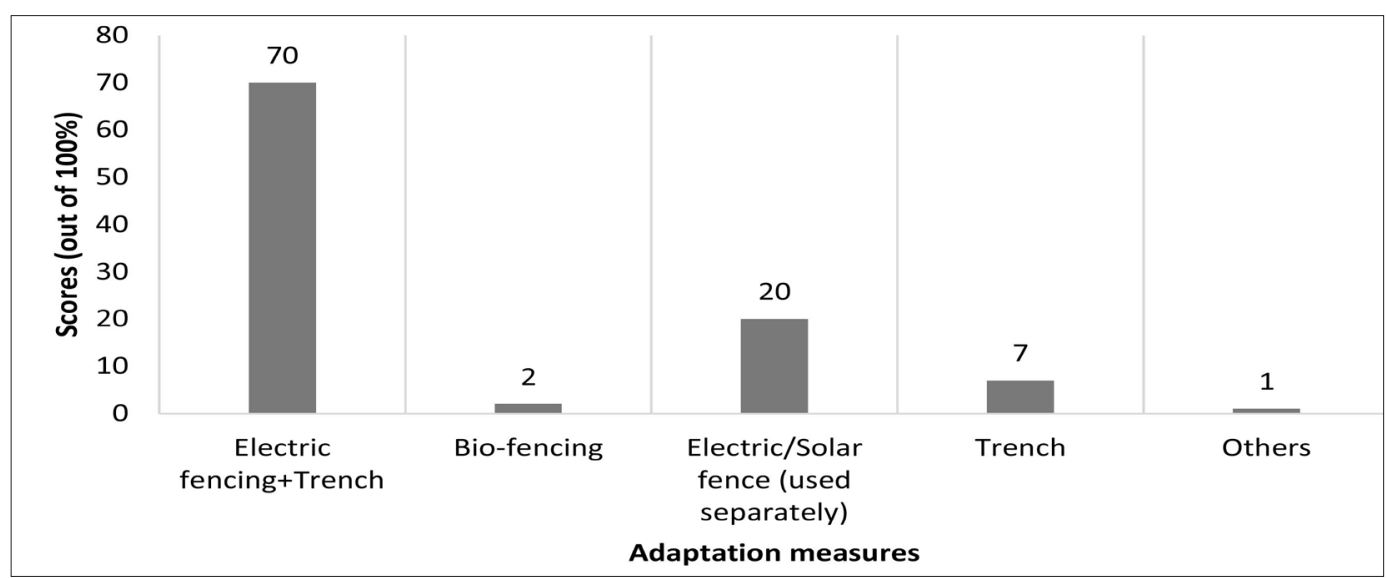

Figure 6. Ranking of Different Adaptation Measures by the Respondents 
As shown in Figure 6, the most preferred adaptation measure of the respondents in coping with rhino impacts was a combination of the electric fencing and trench $(70 \%)$. Likewise 20 per cent opted to use either the electric fence or solar fence (not used together). The third choice of adaptation measure was trench (7\%) followed by bio-fencing (2\%) and Others (1\%).

Adoption of variety of coping and adaptation measures have led to decline in incidents of human-wildlife conflict in the recent times. These days, the local communities have access to modern and technically sound coping and adaptation measures furnished by the support of the CNP and buffer zone user committees (BZUCs). Electric/Solar fencing, trench, mesh wire fencing, and combination of both electric fencing and trench are the common measures in use these days in CNP.

\section{DISCUSSION}

As human populations expand and natural habitats shrink, people and wild animals are increasingly competing over living space and food (Lamarque et al. 2009; Distefano 2004; Madden 2004). The impacts are often huge. People lose their crops, livestock, property, and sometimes their lives. This has also been acknowledged by the Government of Nepal in its Wildlife Damage Relief Guidelines (2013) (first amendment 2015) (GoN 2015). The animals, many of which are already threatened or endangered - in this case, the rhino - come across human settlements to which the humans retaliate using different coping and/or adaptation measures. Human-wildlife conflicts have become more frequent and severe over recent decades as a consequence of human population growth, extension of transport routes and expansion of agricultural and industrial activities which together have led to increased human encroachment on previously wild and uninhabited areas. This has further aggravated the struggle for the available natural habitats and resources (Lamarque et al. 2009; WWF 2008; Madden 2004).

A series of measures have been made available to prevent or mitigate humanwildlife conflict in CNP, and in Nepal as a whole. The most sensible approach in addressing human-wildlife conflict is to implement a combination of shortterm mitigation tools alongside long-term adaptation strategies (Lamarque et al. 2009). In this way, immediate problems are addressed while the rapid development of innovative approaches is fostered to address future issues and eradicate the problem in the long term. In this regard, a number of traditional and modern coping and/or adaptation measures (such as fire sticks, Ghuyetro, making loud sounds, leaving goods/items behind, submerging and/or sinking into a water body, gathering tree support, founding machans and trenches, mesh-wire, fencing (electric, solar, and bio-fencing) either used in isolation or combination, are already in place to reduce incidents of human-wildlife conflict at the CNP. Many of these measures, especially the modern ones, have been set up with the facilitation and support from the Park authorities. Furthermore, additional potential solutions can be selected based on their effectiveness, cost and human and social acceptability. Well-designed human-wildlife conflict management plans which integrate different techniques and are adapted to the nature of the problem can be successful. For instance, managing human-wildlife conflict without destroying 
wildlife or human welfare requires a delicate balance of agricultural extension and wildlife conservation (Treves et al. 2006).

The findings of this study in relation to people's attitude towards rhino conservation and rhinos' presence is quite interesting. While the perception of the local communities toward rhino conservation seem more positive than otherwise, the dissatisfaction with the compensation schemes provided by the GoN, park authorities, and BZCF/ BZUC's in events of wildlife losses is worrying. This is especially worrying or disturbing because it has been found that human-wildlife conflict escalates when local people and communities feel that the needs or values of wildlife are given higher priority over their own needs, or when local institutions and people are inadequately empowered to deal with human-wildlife conflict. If solutions to conflicts are not adequate, local support for conservation declines as a result of which wildlife conservation initiatives suffer, and the economic and social well-being of local people is impaired (Madden 2004).

Dispersal of rhinos outside the PA is a challenge for security but is also an opportunity for partnership with local communities in rhino conservation. The community forests can be used for nature-based tourism (Bookbinder et al. 1998). However, it is to be noted that the security of these rhinos and humanwildlife conflict is a constant challenge for the Park management (Subedi et al. 2013). An important aspect of the work related to minimizing human-wildlife conflict is that it benefits both the rhinos and local human communities, and actively involves these communities. After all, it is about finding solutions that lead to mutually beneficial co-existence. The work has also often led to people being more enthusiastic and supportive of conservation, and has demonstrated that people can live alongside wildlife while developing sustainable livelihoods.

Due to a number of factors as discussed throughout this paper, the rhinos have been venturing into bordering agriculture areas and settlements, resulting in conflict with humans. There needs to be an incentive structure associated with the conservation of the rhinos in this humandominated landscape. Proactive conflict mitigation programs are needed, along with the installation of suitable barriers to prevent crop depredation, and promotion of behavioral adjustments amongst local people to minimize encounters. Lessons can be learned from West Bengal where rhinos and people co-exist as a result of successful conservation, community awareness and development programs (Martin 2006).

The conflict has important consequences for local populations in terms of food security, safety and well-being, for the micro and macro economy, and also for wildlife conservation (Dickman 2010; Lamarque et al. 2009). Considering the current human population growth rate, the increasing demand for natural resources and the growing pressure for access to land, it is clear that human-wildlife conflict will not be eradicated in the near future. Moreover, the effects of climate change are exacerbating these conflicts. Human-wildlife conflict is most likely to exacerbate in the coming years with the increasing human population, combined with climate change and the alternative movements of both humans and wildlife that it is bound to engender (Lamarque et al. 2009; WWF 2008). 
It is important to note that the humanwildlife conflict is not confined to conflicts between human and wildlife. It also involves an equally important dimension of conflict between people who have different goals, attitudes, feelings, and wealth. For instance, human-wildlife conflict may be rooted in struggles among people over access to resources or needs for survival. The conflict may also stem from people who have different needs or levels of need, and questions of who should have access to resources or control over them. Furthermore, the conflict about wildlife is between people with gaps in trust and communication over how to conserve the rhinos and ensure the wellbeing of the local people at the same time. In this regard, the Government of Nepal and the park authorities ought to engage in open and frank discussions with the local communities while deciding the ways forward to addressing this rhino-human conflict.

Finally, this study advances the call of other authors (Heberlein 2004; Manfredo \& Dayer 2004; Mascia et al. 2003) for more constructive collaboration between social scientists and ecologists to manage wildlife. Applied research is needed in both these sciences, as well as in technical solutions. Research is needed to understand and address the levels and complexities of human-human conflicts that are an integral part of human-wildlife conflicts. In fact, more research effort needs to be practically focused and tied to adaptive management of the humanwildlife conflict. Researchers, managers, communities, and practitioners need to exchange ideas and innovations more regularly and in a timely fashion. The findings presented in this study suggests the key question to be addressed: is cohabitation between humans and rhinos still possible in a developing country like Nepal in the context of a twenty-first century ruled by economic profit and globalization?

Conflict alleviation is a two-sided balance where both wildlife and people are in conflict. The goal is thus to enable co-existence and sharing of resources at some level. This is best achieved by addressing both sides of the equation and finding a balance between conservation priorities and the needs of people who live alongside wildlife. Increasing tolerance levels of local communities for wildlife and adapting the human landscape are essential goals, but will always be the most difficult. Reducing human-wildlife conflict is certainly a key means of responding to the aforementioned questions. It is likely to improve both food security, by reducing the impact of wildlife on crops and livestock, and biodiversity conservation, by modifying the negative attitudes of many communities towards wildlife.

\section{CONCLUSION}

The most basic needs-for both humans and rhinos-are food, water and shelter. When basic needs are threatened, conflicts arise. Humans incur losses in the forms of crop and livestock depredation, destruction of stored food, properties, and even lives. Similarly, rhinos too are affected by the retaliation that they face from humans. This is the very premise of human-wildlife conflict that has been discussed in this paper. Furthermore, as growing human population and climate change continues to challenge the existing living state of both the rhinos and the people, both will have to struggle with limited living spaces, water insecurity, and extreme weather. Such conditions could fuel further conflict. 
Therefore various coping and adaptation measures to enable peaceful co-existence of humans and rhinos should adopt a participatory approach in order to ensure local communities' acceptance, support, longevity, and hence, sustainability.

Social science research can advance our understanding in this regard by analysing the already acknowledged sources of human-wildlife conflict. For instance, researches focusing on whether rural populations have to put up with living alongside the rhinos when other alternative livelihood options are available could be one. The issue of relocation of the local communities to avoid humanwildlife conflict is another. If such a relocation is to be carried out, study on who (the government, local-level NGOs, or others) should take the lead in assisting these local communities could be another interesting platform to explore. Further scrutiny of how cases related to humanwildlife conflict are settled in Nepal at present can contribute to informing the policymakers about whether policies, legal and regulatory frameworks supported by viable and functional institutional arrangements are in place in the context of Nepal to address the rhino-human conflict or not. Related to this, a study of the adequacy of the existing compensation schemes is another arena that needs further addressing. A number of key questions should be asked of the compensation schemes (Muruthi 2005). Do they help the rhinos who are in conflict with humans? Are they based on concrete information to be applied effectively? Do they pay the appropriate amount of compensation? Do they target the right culprits? And are they fair, timely, transparent and sustainable? Moreover, the issue of degradation of rhino's natural habitat by the rapid spread of invasive species such as Mikania micrantha in the CNP in Nepal ought to be taken more seriously so as to ensure that the rhinos do not come out of their natural habitats in search of food, thus reducing human-wildlife conflict. The objective of such researches should be to scientifically address the gap in the knowledge related to what mechanism(s) should be adopted so that the locals' support for rhino conservation remains unhinged.

Using applied research with close coordination between social scientists and ecologists, the gaps in our understanding of the relationships between different elements of human-wildlife conflict can be addressed. This would be very useful to explore further in any human-wildlife conflict scenario in Nepal in the future. In conclusion, the capacity to manage rhinorelated threats to human safety and property effectively-without compromising the rhino population viability or human life and livelihoods-is within our grasp. To do so, the Government of Nepal must combine technical expertise with local knowledge and embrace transparent and democratic processes of participatory planning.

\section{REFERENCES}

Bookbinder, M.P., Dinerstein, E., Ri Jal, A., Cauley, H. and Rajouria, A. 1998. Ecotourism's Support of Biodiversity Conservation. Conservation Biology, 12: 1399-1404.

Brandon, K.E. and Wells, M.P. 1992. Planning for People and Parks: Design Dilemmas. World Development, 20(4): 557-570.

Breitenmoser, U. 1998. Large Predators in the Alps: The Fall and Rise of Man's Competitors. Biological Conservation, 83: 279-289.

Budhathoki, P. 2001. Budhathoki, P. 2001. Buffer Zone Initiatives in Nepal - Balancing the Scales. Seminar on Buffer Zone Management - Ecology versus Economy. Wageningen, The Netherlands. 
Dickman, A.J. 2010. Complexities of Conflict: The Importance of Considering Social Factors for Effectively Resolving Humanwildlife Conflict. Animal Conservation, 13(5):458-466

Dinerstein, E. 2003. The Return of the Unicorns: The Natural History and Conservation of the Greater One-horned Rhinoceros. New York, NY: Columbia University Press.

Distefano, E. 2004. Human-wildlife Conflict Worldwide: Collection of Case Studies, Analysis of Management Strategies and Good Practices. Rome: Food and Agriculture Organization.

DNPWC. 2006. Annual Report of Department of National Park and Wildlife Conservation. Department of National Park and Wildlife Conservation, Government of Nepal.

DNPWC. 2007. Tiger Conservation Action Plan for Nepal. Department of National Park and Wildlife Conservation, Government of Nepal.

Foose, T. J. and van Strien, N. J. 1997. Asian Rhinos: Status Survey and Conservation Action Plan. Gland: The World Conservation Union (IUCN).

GoN. 2015. Revised Wildlife Damage Relief Guideline 2013 (first amendment 2015). Ministry of Forests and Soil Conservation, Government of Nepal.

Heberlein, T.A. 2004. Fire in the Sistine Chapel: How Wisconsin responded to chronic wasting disease. Human Dimensions of Wildlife, 9: 165-179.

Inskip, C. and Zimmermann, A. 2009. Human Field Conflict: A review of patterns and priorities worldwide. Oryx, 43(1): 18-34.

IUCN. 2008. IUCN Red List 2007. International Union for Conservation of Nature. (http:// www.iucnredlist.org accessed 7 March, 2016).

Jnawali,S.R.1989.ParkPeople Conflict:Assessment of Crop Damage and Human Harassment by Rhinoceros (Rhinoceros unicornis) in Sauraba Area Adjacent to the Royal Chitwan National Park, Nepal. MSc Thesis, Agriculture University of Norway, Norway. (http:// www.rhinoresourcecenter.com/index.php ? $\mathrm{s}=1 \&$ act=pdfviewer\&id=1312325452\&fol der=131accessed on 8 March, 2016)

Jorgensen, C. J., Conley, R. H., Hamilton, R. J. and Sanders, O. T. 1978. Management of Black Bear Depredation Problems. Proceedings of the Eastern Workshop on Black Bear Management and Research, 4: 297-321.
Karanth, K. U. and Madhusudan, M. D. 2002. Mitigating Human-wildlife Conflicts in Southern Asia. In: J. Terborgh, C. P. Van Schaik, M. Rao, and L. C. Davenport (Eds.), Making Parks Work: Identifying Key Factors to Implementing Parks in the Tropics (pp. 250264). Covelo, CA: Island Press.

Kharel, F.R. 1997. Agricultural Crop and Livestock Depredation by Wildlife in Langtang National Park Nepal. Mountain Research and Development, 17(2): 127-134.

Knight, J. 2003. Waiting for Wolves in Japan. Oxford: Oxford University Press.

Lamarque, F., Anderson, J., Fergusson, R., Lagrange, M., Osei-Owusu, Y. and Bakker, L. 2009. Human-wildlife Conflict in Africa: Causes, Consequences and Management Strategies. Rome: Food and Agriculture Organization.

Ledec, G. and Woodland, R. 1990. Wild Lands: Their Protection and Management in Economic Development. Washington DC, USA: The World Bank.

Loe, J. and Roskaft, E. 2004. Large Carnivores and Human Safety- A Review. Ambio, 33: 283288.

Madden, F. 2004. Creating Coexistence between Humans and Wildlife: Global Perspectives on Local Efforts to Address Human-wildlife Conflict. Human Dimensions of Wildlife, 9: 247-257.

Manfredo, J. and Dayer, A. A. 2004. Concepts for Exploring the Social Aspects of Humanwildlife Conflict in a Global Context. Human Dimensions of Wildlife, 9: 317-328.

Martin, E.B. 2006. Policies that Work for Rhino Conservation in West Bengal. Pachyderm, 41: 74-84.

Mascia, M. B., Brosius, J. P., Dobson, T. A., Forbes, B. C., Horowitz, L., McKean, M. A. and Turner, N. J. 2003. Conservation and the Social Sciences. Conservation Biology, 17(3): 649-650.

McLean, J. and Straede, S. 2003. Conservation, Relocation, and the Paradigms of Park and People Management: A Case Study of Padampur Villages and the Royal Chitwan National Park, Nepal. Society and Natural Resources, 16: 509-526.

Muruthi, P. 2005. Human Wildlife Conflict: Lessons Learned from AWF's African Heartlands. Unpublished Report. Nairobi: AWF. 
Nepal, S. K. and K. E. Weber. 1993. Struggle for Existence: Park-people Conflict in the Royal Chitwan National Park, Nepal. HSD Monograph 28. Asian Institute of Technology, Bangkok, Thailand.

Ogra, M. and Badola, R. 2008. Compensating Human-Wildlife Conflict: Protected Area Communities: Ground-Level Perspectives from Uttarakhand, India. Human Ecology, 36(5): 717-729.

Packer, C., Ikanda, D., Kissui, B. and Kushnir, H. 2005. Lion Attacks on Humans in Tanzania. Nature, 436: 927-928.

Perez, E. and Pacheco, L.F. 2006. Damage by Large Mammals to Subsistence Crops within a Protected Area in a Montane Forest of Bolivia. Crop Protect, 25: 933-939.

Pimentel, D., Zuniga, R. and Morrison, D. 2005. Update on the Environmental and Economic Costs Associated with Alieninvasive Species in the United States. Ecological Economics, 52: 273-288.

Rhino Count. 2015. National Rhino Count. Department of National Parks and Wildlife, Government of Nepal.

Sharma, U. R. and Shaw, W.W. 1993. Role of Nepal's Royal Chitwan National Park in Meeting the Grazing and Fodder Needs of Local People. Environmental Conservation, 20(2): 139-142.

Subedi, N., Jnawali, S.R., Dhakal, M., Pradhan, N.M.B., Lamichhane, B.R., Malla, S., Amin, R. and Jhala, Y.V. 2013. Population Status, Structure and Distribution of the Greater One-horned Rhinoceros Rbinoceros unicornis in Nepal. Oryx, 47(3): 352-360
Thirgood, S., Woodroffe, R. and Rabinowitz, A. 2005. The Impact of Human-wildlife Conflict on Human Lives and Livelihoods. In: R. Woodroffe, S. Thirgood and A. Rabinowitz (Eds.), People and Wildlife, Conflict or Coexistence? (pp. 86-106). Cambridge, UK: Cambridge University Press.

Treves, A. and Naughton-Treves, L. 2005. Evaluating lethal control in the management of human- wildlife conflict. In Woodroffe, R., Thirgood, S. \& Rabinowitz, A. (Eds.), People and wildlife, conflict or coexistence? (pp. 86-106). Cambridge, UK: Cambridge University Press.

Treves, A., Wallace, R.B., Naughton-Treves, L., and Morales, A. 2006. Co-Managing Human-Wildlife Conflicts: A Review. Human Dimensions of Wildlife, 11: 383-396

Wang S.W. and Macdonald D.W. 2005. Livestock Predation by Carnivores in Jigme Singye Wangchuck National Park, Bhutan. Biological Conservation, 129(2006): 558-565

Wells, M., Brandon, K. and Hannah, L. 1992. People and Parks- Linking Protected Area Management with Local Communities. The World Bank/WWF/USAID Washington.

Woodroffe, R., Thirgood, S. and Rabinowitz, A. (Eds.) 2005. People and Wildlife: Conflict or Coexistence? Cambridge: Cambridge University Press.

WWF. 2008. Common Ground: Solutions for Reducing the Human, Economic and Conservation Costs of Human Wildlife Conflict. Gland: WWF International 